sapareceram os Xamãs, protagonistas da religião tapirapé, protetores da tribo contra perigos sobrenaturais e sem os quais não havia esperança de sobrevivência. Poucos estavam dispostos a aprender $\circ$ trançado de cestos, técnica bem desenvolvida pelos antecessores. E, o que é mais importante, conforme se acelera êste processo, os tapirapés tornam-se acessíveis a novas doutrinas, principalmente à catequese.

O livro é fartamente ilustrado, com fotografias e desenhos de objetos, instrumentos, pessoas, danças, festas e cenas da vida cotidiana, o que ajuda a dar uma imagem mais completa desta tribo do Brasil Central. O trabalho é um documento precioso para o conhecimento etnológico do indígena brasileiro, servindo como achegas aos estudos das ciências humanas.

A obra traz, em apêndice, um estudo do professor Emílio Willens, Caracteristicas antropométricas dos tapirapés.

MARISA SAENZ LEME

\title{
A Pesquisa Histórica no Brasil
}

Por José Honório Rodrigues. São Paulo, Companhia Editôra Nacional, 1969. 283 p.

José Honório Rodrigues reformulou seu livro A pesquisa histórica no Brasil $\left(1 .^{\mathrm{a}}\right.$ edição em 1952), preocupado em enfrentar "novas definições muito difíceis" e em "atender ao espírito da mocidade estudiosa". Por isso, acrescentou-lhe alguns capítulos e modificou-lhe as noções preliminares.

O autor dá informações preciosas aos pesquisadores iniciantes, alertando-os das dificuldades no contato e manejo dos documentos. Além disso, mostra que, infelizmente, o Estado não se interessa em recolher e preservar o material histórico; daí ser fraco o apoio às eventuais tentativas de aperfeiçoamento $\mathrm{e}$ renovação das instituições que se dedicam à pesquisa. Por sua vez, os órgãos arquivísticos que, de maneira geral, mostraram-se negligentes no trabalho de preservação do material primário, muitas vêzes não puderam agir melhor por falta de recursos.

Apesar dessas dificuldades, a gestão de José Honório Rodrigues como Diretor do Arquivo Nacional (assumiu a direção em 1958), possibilitou certa ação positiva. Nessa época, êle levanta a idéia da criação de um Instituto Nacional de Pesquisa Histórica, que teria a finalidade de preencher as lacunas de nossas fontes de trabalho, assim como a aperfeiçoamento dos órgãos já existentes. Parece-lhe imprescindível a criação de um organismo dessa natureza, que planejasse a organização dos instrumentos do trabalho histórico, recolhendo e inventariando papéis referentes ao Brasil, localizados no país ou no exterior.

Depois dessas colocações, o autor acentua que "a pesquisa histórica é a descoberta cuidadosa, exaustiva e diligente de novos fatos históricos, a busca de documentos, que provam a existência dos mesmos, permita sua incorporação ao escrito histórico ou a revisão e interpretação nova da história", e que "a pesquisa deve ser definida em têrmos de serviço público e deve ser sistematizada, planejada e ordenada". O desenvolvimento da pesquisa histórica e o aperfeiçoamento da historiografia são, para o autor, resultados da preservação e do contrôle documentais. Por isso, sua atenção se dirige para o estado em que se encontram nossos órgãos arquivísti$\cos$, públicos ou privados. Um capítulo especial é dedicado ao exame das bibliotecas e arquivos, nacionais ou estrangeiros. O livro contém uma relação sistematizada e ordenada dessas instituições. 
José Honório Rodrigues considera dever do Estado a iniciativa e o apoio ao recolhimento das fontes. Daí enfocar a pesquisa públicohistórica brasileira, a partir de sua origem com a criação do Instituto Histórico e Geográfico Brasileiro, inspirado nos princípios da escola alemã. Considera-o, ao lado da Biblioteca Nacional, elemento vital da historiografia brasileira, por suas iniciativas de investigação em arquivos estrangeiros, principalmente na fase imperial. Insiste na deficiência dêsse trabalho durante o perícdo republicano. Fornece ainda uma relação de pessoas enviadas ao estrangeiro, com o objetivo de recolher o maior número possível de documentos referentes à nossa história. É o caso de Varnhagen, João Francisco Lisboa, Gonçalves Dias, João Caetano da Silva, Ramiz Galvão, José Higino, Rio Branco, Oliveira Lima, Capistrano de Abreu, Rodolfo Garcia, Jaime Cortesão e o próprio José Honório. Revelam-se as iniciativas feitas pelo instituto, no sentido de explorar os arquivos brasileiros estaduais, municipais, provinciais, eclesiásticos e privados. Refere-se aos trabalhos do Ministério das Relações Exteriores, interrompidos pràticamente a partir do período republicano. $\mathrm{Na}$ exposição sôbre cada um dos enviados ao estrangeiro e às províncias brasileiras, aponta as falhas e os méritos de cada trabalho, além do papel dos elementos na historiografia nacional.

Acrescenta-se um problema de fundamental importância e atualidade: são as perspectivas para o estudo de história moderna e contemporânea. O desenvolvimento do serviço público vem acarretar uma proliferação de documentos que constituem amplas fontes aos dois setores. De acôrdo com o autor, é necessário controlar o entusiasmo, pois a essas fontes correspondem graves problemas. A progressão geométrica com que êsse material surge exige critérios de avaliação, além de novas técnicas arquivísticas. Parece-lhe a solução mais moderna e prática, a utilização da microfilmagem: permite a conservação dos documentos que não mais suportam o contato freqüente; a facilidade de organização arquivística; o barateamento e facilidade na publicação de documentos públicos atuais, recurso já empregado nos Estados Unidos. Outro aspecto é o filme como documento histórico, e as novas técnicas de critica interna e crítica externa que envolve. Encontramos, ainda, considerações sôbre a inter-relação entre literatura e história.

Mais uma perspectiva para a historiografia brasiletra é apresentada: o desenvolvimento dos arquivos econômicos de emprêsas particulares e de sindicatos de trabalhadores. Segundo o autor, existem poucos ensaios sôbre a matéria e, em sua maioria, medíocres (aborda alguns casos).

Esclarecimentos de ordem técnica são encontrados num capítulo relativo aos instrumentos de trabalho histórico. Discute-se o acesso do público aos documentos (principalmente atuais): um privilégio ou um direito legal? Assim, comenta-se o comportamento de alguns países, inclusive o Brasil, quando a grande preocupação é a segurança nacional. A necessidade de acesso a um material mais recente, devido aos estudos modernos e contemporâneos, exige cada vez mais a mudança de atitude quanto às restriçôes de consulta.

Finalmente, o autor acentua a relação existente entre o patrimônio histórico e a constituição nacional. Esta, apesar de proibir a saída de acervos documentais e bibliotecas (compradores principalmente norteamericanos), amplia em demasia as tarefas do patrimônio histórico e artístico nacional.

Sintetizando, tôdas essas críticas feitas aos trabalhos de recolhimento, preservação e catalogação, induzem-nos a afirmar que, se é impossível a criação de um Instituto Nacional de Pesquisa Histórica, alguma coisa deve ser feita no sentido de permitir um verdadeiro trabalho histórico dentro do Brasil, viável na medida em que possuir elementos mínimos para sua perfeita realização.

CÉlia REIS CAMaRgo 